\title{
Analysis of Loading Change Effect to Boat Velocity on a 2.5GT Fishing FRP Boat with a Field Test
}

\author{
Syerly Klara ${ }^{1}$, Faisal Mahmuddin ${ }^{2}$, Muhammad Muas ${ }^{3}$ \\ ${ }^{1}$ Marine Engineering Department, Engineering Faculty, Hasanuddin University, Makassar. Email: \\ elikapal@yahoo.com \\ ${ }^{2}$ Marine Engineering Department, Engineering Faculty, Hasanuddin University, Makassar. Email: \\ f.mahmuddin@gmail.com \\ ${ }^{3}$ Marine Engineering Department, Engineering Faculty, Hasanuddin University, Makassar. Email: \\ muasmhmmd@gmail.com
}

\begin{abstract}
:
In order to determine the effect of load change to ship velocity on a 2.5 GT fishing boat, a field test is conducted in the present study. The boat model used in the field test is an actual size boat made from fiber reinforced plastic (FRP) material. The boat is powered by 2 (two) 15 HP direct drive engines each equipped with 3-bladed single screw propeller. Two loading cases are investigated and analyzed which are no load case and with load case. For each case, 4 (four) engine power variations are performed which are $25 \%, 50 \%, 75 \%$ and $100 \%$. The main parameters measured are boat draught, engine power percentage, shaft revolution speed and boat velocity. From the field test, it is found that even though the propulsion performance increases larger loading and displacement, the increased boat resistance due to larger wetted surface make the boat velocity reduces.
\end{abstract}

Keywords: fishing boat, loading effect, ship velocity, field test.

\begin{abstract}
Abstrak
Guna menentukan pengaruh perubahan beban terhadap kecepatan kapal pada sebuah kapal ikan 2.5 GT, sebuah percobaan lapangan dilakukan pada penelitian ini. Kapal yang digunakan adalah sebuah dengan ukuran sebenarnya yang terbuat dari bahan fiberglass (FRP). Kapal ini digerakkan oleh 2 (dua) mesin 15 HP yang dilengkapi dengan mesin tanpa roda gigi yang dilengkapi dengan masing-masing sebuah propeller ulir tunggal 3 (tiga) daun. 2 (dua) kasus pembebanan diselidiki dan dianalisa yakni kasus tanpa dan dengan beban. Pada setiap kasus, 4 (empat) variasi daya mesin dilaksanakan yakni 25\%, 50\%, 75\%, dan 100\%. Parameter utama yang diukur adalah sarat, persentase daya mesin, kecepatan putaran poros dan kecepatan kapal. Dari penelitian, diketahui bahwa meskipun kinerja sistem propulsi meningkat meningkat pada kasus pembebanan yang lebih besar, tahanan kapal yang meningkat akibat sarat yang lebih besar membuat kecepatan kapal menurun
\end{abstract}

Kata Kunci: kapal ikan, pengaruh pembebanan, kecepatan kapal, percobaan lapangan.

\section{Introduction}

Due to vast area of ocean territory, Indonesia owns abundant maritime resources including in fisheries sector. Therefore, significant efforts haven been made by the Indonesian Government to support the utilization and exploitation of this sector to increase revenue and prosperity of the society especially for the ones who are living in the coastal areas.

One example of this support is providing and distributing fishing boats to fishermen across the country. In 2010, the Ministry of Marine Affairs and Fisheries (KKP) had a working plan to distribute 1000 30GT fishing boats until 2014 known as Inka Mina Project (KKP, 2013). Even though the project had faced several problems and considered to be below the initial expectation, several similar projects have been executed in the ensuing years.

However, some problems are faced by the fishermen who received the assistance from the government. One of the problems is the relatively expensive maintenance and operational costs of the received ship. Therefore, realizing that bigger ship will mean more expensive operational and maintenance costs, the government shifts its strategy by providing smaller fishing boats. Not only 
changing the size but also the ships material from wooden ship to fiber reinforced plastic (FRP) material. In 2017, the same ministry are distributing many more smaller fiberglass boats to fishermen compared to the previous years (KKP, 2017).

However, even though some research have been performed on these boats technical and economic performances such as the ones performed by Atmanegara (2016), Fauzi (2016) and Mira (2013), comprehensive tests and measurements on hull and propulsion system perfomances are still relatively rare and difficult to find. Hull and propulsion system performances are 2 (two) of the most important factors determining the effeciency of the boat.

Therefore, in the present study, a field test of a $2.5 \mathrm{GT}$ fishing boat is conducted. The boat is made from FRP material and the hull shape is very similar to the ones distributed by the Ministry of Marine Affairs and Fisheries in recent years. Example the fishing boats distributed by the KKP Ministry is shown in the following figure.

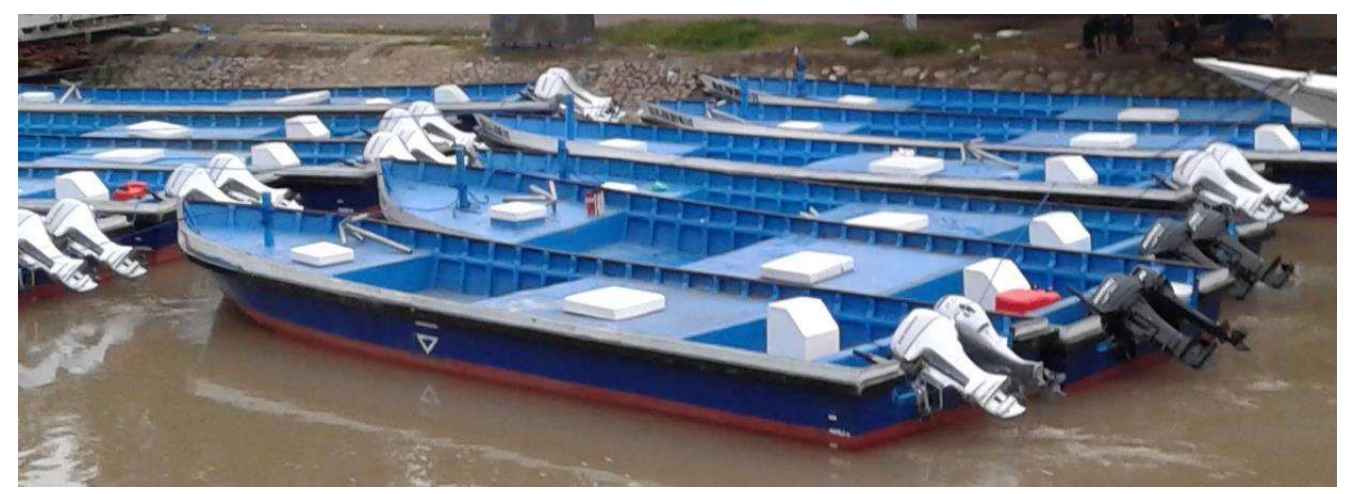

Figure 1. Example of Fishing Boats Distributed to Fishermen by the Ministry of Marine Affairs and Fisheries of Indonesia

However, even though the material and shape of the boat model used in the present study is similar to ones distributed by the goverment, the propulsion system of the boat used in the present study is modified in order to lower the initial cost and increase the propulsion performance. Instead of using an expensive outboard engine shown in Fig. 1, the boat model is powered by 2 (two) inboard engines with much lower price.

The main aim of the present study is to determine and analyze the effect of loading change to the boat velocity. Therefore, 2 (two) different loading cases are perfomed which are no load and with load cases. For each case, 4 (four) engine power levels are set for data collection and measurements. From this test, it is found the even though larger draft will increase the propulsion performance, the increase of displacement and hull resistance reduces the boat velocity.

\section{Methods}

In the present study, measurement and data collection will be performed by conducting a field test. The test is conducted by running the boat model using its own propulsion system and then measuring the main parameters such as draught, shaft revolution speed, and boat velocity. In the field test, a fishing boat with $2.5 \mathrm{GT}$ capacity is used. The boat is made from fiber reinforced plastic (FRP) material. The photos of the boat models are shown in the following figures. 


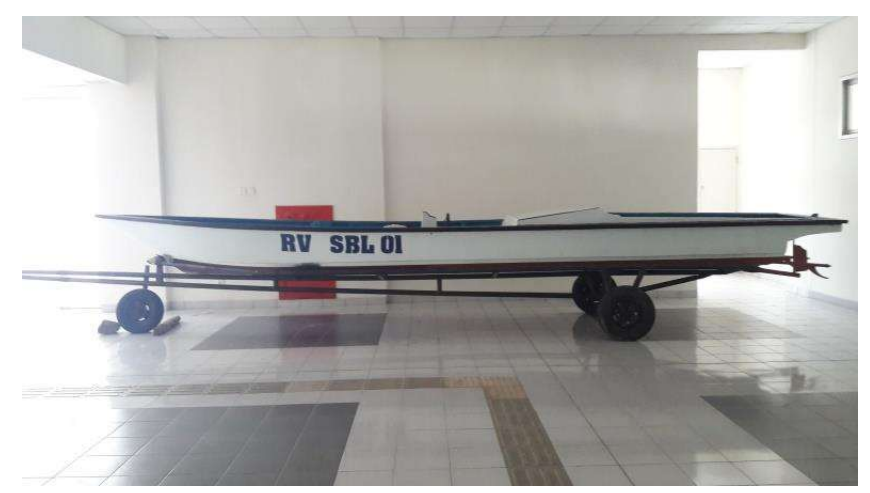

(a)

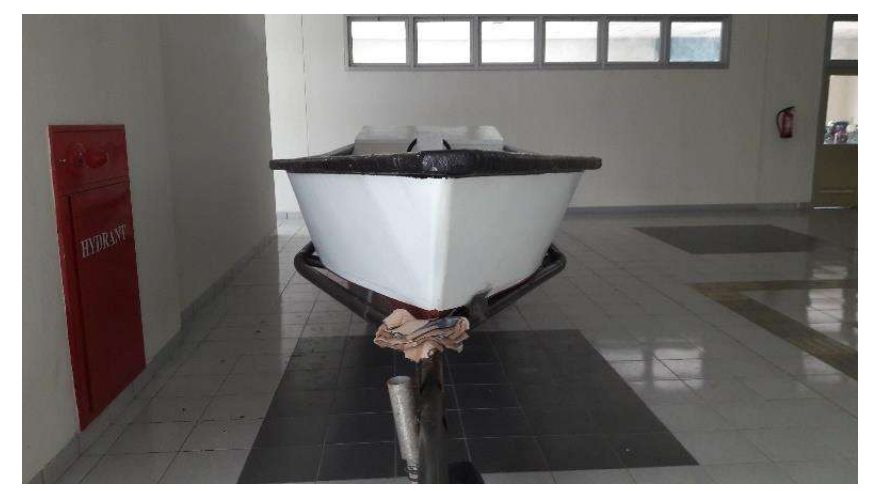

(b)

Figure 2. Boat Model Used in the Field Test

The boat model has the main particulars as shown in the following table.

Table 1. Boat model particulars

\begin{tabular}{lc}
\hline \multicolumn{1}{c}{ Parameter } & $\begin{array}{c}\text { Value } \\
\text { (Meter) }\end{array}$ \\
\hline Length overall (LOA) & 7.93 \\
Breadth (B) & 1.37 \\
Draught (T) & 0.18 \\
Height (H) & 0.8 \\
\hline
\end{tabular}

In order to observe more detail the hull shape of the boat model, the body plan of the boat is shown in the following figure.

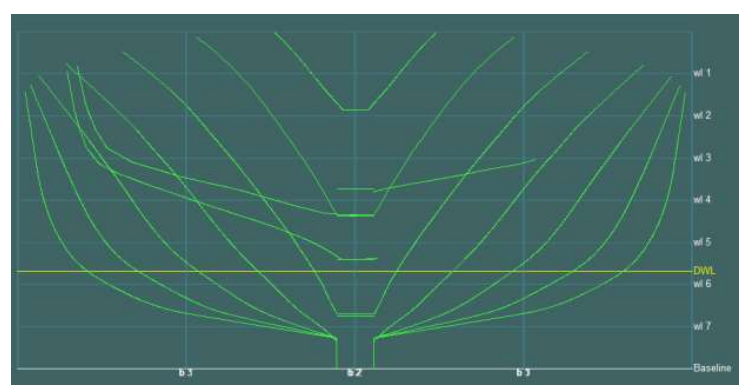

Figure 3. Body Plan of Boat Model 
The boat is powered by 2 (two) 15 HP 4 -stroke engines. More detail about the engine specifications are shown in Table 2 and photo of one of the engines is shown in Figure 4.

Table 2. Boat engine specifications

\begin{tabular}{ll}
\hline Brand & Jiang Dong \\
Model & GX420 \\
Type & 4-stroke, single cylinder \\
& with air cooled \\
Max. output (HP/rpm) & $15 / 3600$ \\
Max. torque (Nm/rpm) & $29.3 / 2500$ \\
Start mode & Recoil \\
Gasoline tank capacity & 6.5 \\
(L) & \\
SFOC (gr/HP-hour) & 260 \\
Bore (mm) & 90 \\
Stroke $(\mathrm{mm})$ & 66 \\
Compression ratio & $8: 1$ \\
Dimension & $530 \times 405 \times 480 \mathrm{~mm}$ \\
Net weight $(\mathrm{kg})$ & 15 \\
\hline
\end{tabular}

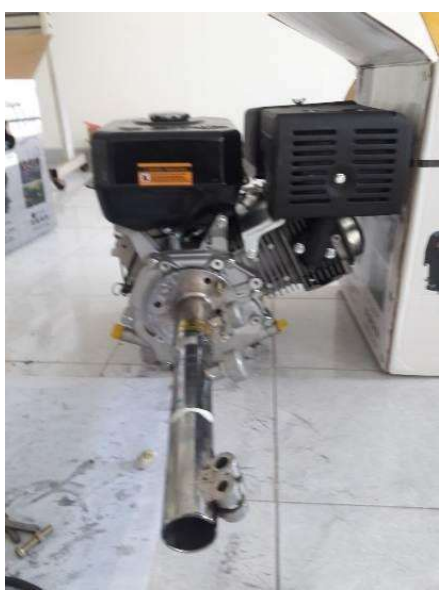

Figure 4. Boat Engine

In the experiment, 2 (two) loading variations are measured which are no load case and with load case. For each case, 4 (four) engine power variations are performed which are when engine power equals to $25 \%, 50 \%, 75 \%$ and $100 \%$.

\section{Results and discussions}

As described previously, 2 (two) cases of loading are measured and investigated. The first case is called "no load" case where the draught is $0.18 \mathrm{~m}$ and the second case is called "with load" case where the draught is $0.22 \mathrm{~m}$. For each case, 4 (four) engine power variations are performed which are when engine power equals to $25 \%, 50 \%, 75 \%$ and $100 \%$.

For both cases, the boat shaft revolution speed is measured. The results of measurements are shown in the following figure:

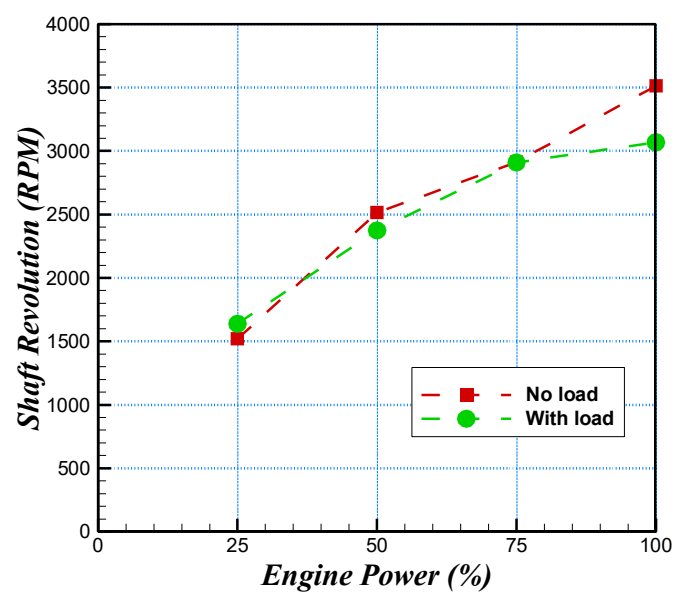

Figure 5. Shaft Revolution Speed for No Load and with Load Cases

It can be seen from Fig. 5 that the shaft revolution speed has a slight increase in the first quarter of engine power range but then reduction occurs especially at the maximum engine power. From this trend, it could be said that the shaft revolution speed is reduced when the load increases. The reduction is mainly due to the shaft torque increase for larger load condition. 
Moreover, because the boat has 2 (two) engines, the shaft revolution speed for both engines are also measured. The terms port and starboard side are used to represent the shaft position depending on their closest position to the respected side of the boat. The comparison between these 2 (two) shafts revolution speed for the case of engine power $25 \%$, with load case is shown in the following figure.

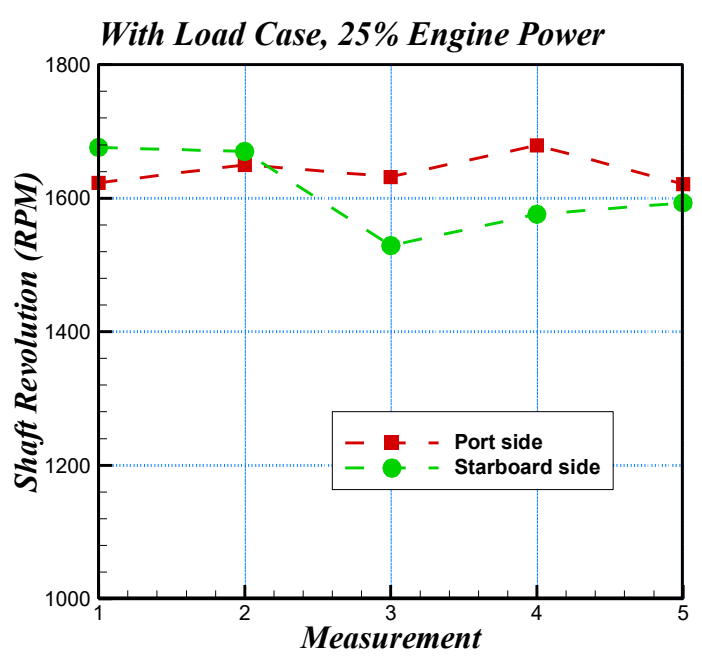

Figure 6. Comparison between Shaft Revolution Speed at Port and Starboard Sides for Engine Power $25 \%$, with Load Case.

It can be observed from Fig. 6 that 5 (five) times measurements were performed. For each measurement, a difference of shaft revolution speed can be seen. The average difference is $32 \mathrm{rpm}$ or approximately $2 \%$ from average measured speed. The difference can be considered to be relatively small so it can be tolerated in the present study. The difference is attributed to manual adjustment of engine power.

In the field test, the shaft revolution speed is measured regularly in order to know their variation over a certain time period. The obtained values in with load case are shown in the following figure.

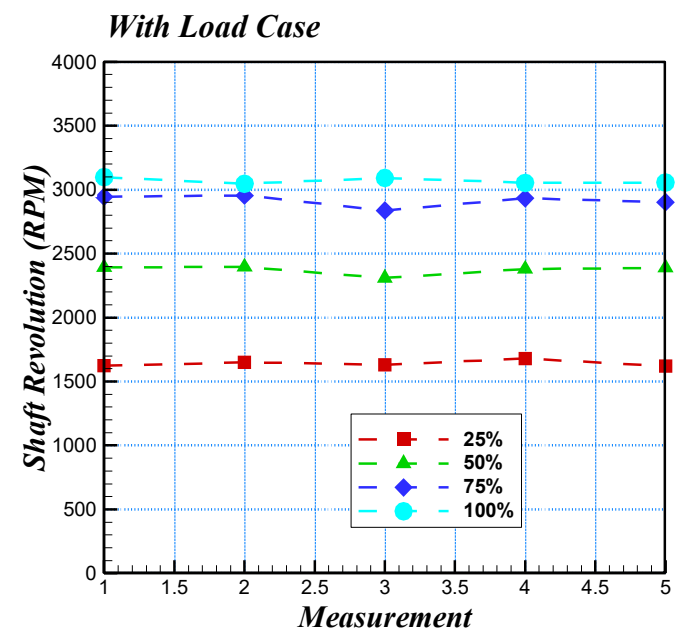

Figure 7. Shaft Revolution Speed of Port Side Shaft, with Load Case

Fig. 7 shows the variation of shaft revolution speed for 4 (four) engine power conditions. Only one shaft is shown by assuming the other shaft has the similar characteristics. From Fig. 7, it can be seen 
that the variation is relatively small so by taking the average, it could be considered representing the true value of shaft revolution speed measurement.

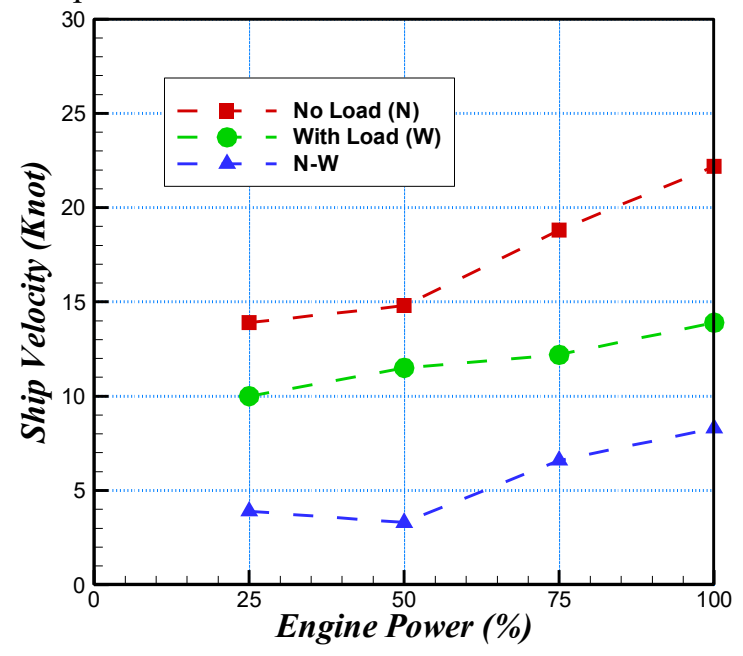

Figure 8. Boat Velocity Comparison between No Load and With Load Cases

It can be seen from Fig. 8 that in all measurement points, the boat velocity reduction can be observed clearly. In no load conditions, the maximum velocity is more than 22 knots while for with load case, the maximum velocity is reduced to approximately 14 knots. Moreover, it can be also observed that generally the reduction increases as the power engine percentage increases which can be represented by the difference between these 2 cases and shown by the blue line in Fig. 8 . Considering that the reduction in shaft revolution is small, then the reduction can be attributed to the increase of boat displacement which consequently increases the boat resistance.

\section{Conclusion}

In the present study, analysis of a fishing boat has been performed. The research data for analysis are measured and taken from a field test. An actual size FRP fishing boat with gross capacity of 2.5 ton is used in the field test. 2 (two) cases were evaluated which are no load case and with load case. It is found that there is only slight reduction of shaft propeller revolution due to boat load. Moreover, it can also be confirmed that with load case has a bigger resistance and lower speed compared to no load because of the increased wetted surface and displacement of the boat.

\section{Acknowledgments}

The Authors wishing to acknowledge JICA C-BEST Project of Engineering Faculty, Hasanuddin University for funding this research.

\section{References}

Atmanegera, R. E. P., Pribadi, T.W., and Arif, M. S. (2016) 'Analisis Tekniks dan Ekonomis Pembangunan Kapal Ikan 30GT Konstruksi FRP Metode Vacuum Infusion', Jurnal Teknik ITS, Vol. 5, No. 1, pp: G25G30.

Fauzi, M. R. R., Pribadi, S. R. W., and Soejitno. (2016) 'Studi Penerapan Kebijakan Subsidi Bunga pada Galangan Kapal untuk Pembangunan Kapal Ikan 30 GT', Jurnal Teknik ITS, Vol. 5, No. 1, pp: G37-G41.

Kementerian Kelautan dan Perikanan (KKP). (2013) Daftar Rincian Alokasi Kapal Ikan Inka Mina Berdasarkan Provinsi/Kabupaten/Kota, Jakarta, Kementerian Kelautan dan Perikanan.

Kementerian Kelautan dan Perikanan (KKP). (2017) Perkuat Armada Kapal Nasional, KKP Bangun 1.068 Kapal Perikanan, available from - http://www.djpt.kkp.go.id/read/perkuat-armada-kapal-nasional-kkpbangun-1068-kapal-perikanan

Mira (2013) 'Performance of Ship Assistance Program for Fisheries', Jurnal Ekonomi Pembangunan, Vol. 19, No. 2 pp: 180-191. 